\title{
Comunicação suplementar e/ou alternativa (CSA): fatores favoráveis e desfavoráveis ao uso no contexto familiar
}

\author{
Simone Infingardi Krüger ${ }^{1}$
}

Krüger SI. Comunicação suplementar e/ou alternativa (CSA): fatores favoráveis e desfavoráveis ao uso no contexto familiar [dissertação]. Curitiba: Universidade Tuiuti do Paraná; 2009.

O estudo teve por objetivo analisar fatores favoráveis e desfavoráveis ao uso da Comunicação Suplementar e/ou Alternativa (CSA) no contexto familiar, enfocando a prancha de CSA. Participaram deste estudo 20 pais e/ou responsáveis de crianças inseridas em uma escola especial de Curitiba, destinada a indivíduos com deficiências motoras e múltiplas. Tais sujeitos foram divididos em dois grupos: o Grupo G1, composto por nove sujeitos que utilizam CSA no contexto familiar e o Grupo G2 composto por 11 sujeitos que não a utilizam. Os dados foram levantados a partir da aplicação de questionários semi-estruturados com questões relativas: à finalidade do uso da prancha na escola, à sua contribuição no desenvolvimento da criança, aos motivos que levam os pais a usarem ou a não usarem, ao preparo que obtiveram quanto ao uso da CSA e a situações de uso no contexto familiar. Dentre os principais aspectos favoráveis ao uso da CSA no contexto familiar, verificaram-se os seguintes: a frequência de preparo dos pais para o uso da CSA; o reconhecimento da CSA como recurso linguístico; o reconhecimento da dificuldade de interpretar e atribuir sentido às manifestações de linguagem; o entendimento de que a CSA favorece o desenvolvimento da oralidade; o uso da CSA para atendimento das necessidades básicas; o uso da CSA para facilitar as interações fora do contexto familiar. Os principais aspectos desfavoráveis observados foram os seguintes: os pais julgam compreender seus filhos sem uso da CSA; a CSA não atende às expectativas dos pais; falta auxílio e preparo para o uso da CSA; o uso é restrito à função escolar; há dificuldades e limitações motoras com a prancha de comunicação. Podese apreender que o entendimento da CSA como recurso linguístico e mediador das interações amplia as possibilidades de significar/interpretar a linguagem. Ressalta-se a importância de intervenções fonoaudiológicas com os familiares que potencializem suas condições de cuidadores de seus filhos, especialmente no que se refere às formas de participação nos processos de apropriação da linguagem. Evidenciase também a importância de um trabalho multidisciplinar que ofereça elementos teórico-práticos que auxiliem o uso efetivo da CSA no contexto familiar. Afirma-se, por fim, a necessidade de estudos e intervenções que democratizem recursos alternativos de linguagem, viabilizando a sujeitos com limitações significativas de oralidade modos de participação social com maior autonomia.

Dissertação apresentada ao Programa de Pós-Graduação em Distúrbios da Comunicação da Universidade Tuiuti do Paraná como requisito parcial para a obtenção do título de Mestre em Distúrbios da Comunicação, sob orientação da Profa. Dra. Ana Paula Berberian.

Fontes de auxilio à pesquisa: bolsa de mestrado CNPq.

(1) Mestre, Fonoaudióloga clínica - Curitiba (PR), Brasil; Bolsista CNPq modalidade DTI.

Endereço para correspondência: Simone Infingardi Krüger. R. Margarida Dallarmi, 101, Curitiba (PR), Brasil, CEP: 82015-690. E-mail: simonekrueger@hotmail.com. 